\title{
Hepatitis B virus infection in Nigeria: a systematic review and meta-analysis of data published between 2010 and 2019
}

\author{
Busayo I. Ajuwon ${ }^{1,2^{*}}$, Isabelle Yujuico ${ }^{1}$, Katrina Roper ${ }^{1}$, Alice Richardson ${ }^{3}$, Meru Sheel ${ }^{1}$ and Brett A. Lidbury ${ }^{1,4}$
}

\begin{abstract}
Background: Hepatitis B virus (HBV) is an infectious disease of global significance, causing a significant health burden in Africa due to complications associated with infection, such as cirrhosis and liver cancer. In Nigeria, which is considered a high prevalence country, estimates of HBV cases are inconsistent, and therefore additional clarity is required to manage HBV-associated public health challenges.
\end{abstract}

Methods: A systematic review of the literature (via PubMed, Advanced Google Scholar, African Index Medicus) was conducted to retrieve primary studies published between 1 January 2010 and 31 December 2019, with a randomeffects model based on proportions used to estimate the population-based prevalence of HBV in the Nigerian population.

Results: The final analyses included 47 studies with 21,702 participants that revealed a pooled prevalence of 9.5\%. A prevalence estimate above $8 \%$ in a population is classified as high. Sub-group analyses revealed the highest HBV prevalence in rural settings (10.7\%). The North West region had the highest prevalence (12.1\%) among Nigeria's six geopolitical zones/regions. The estimate of total variation between studies indicated substantial heterogeneity. These variations could be explained by setting and geographical region. The statistical test for Egger's regression showed no evidence of publication bias $(p=0.879)$.

Conclusions: We present an up-to-date review on the prevalence of HBV in Nigeria, which will provide critical data to optimise and assess the impact of current prevention and control strategies, including disease surveillance and diagnoses, vaccination policies and management for those infected.

\section{Background}

Hepatitis B virus (HBV) is an Hepadnavirus that infects liver cells, and was responsible for an estimated 820,000 deaths in 2019; for example, from the subsequent development of hepatocellular carcinomas (HCC) [1]. An estimated $3.6 \%$ of the global population is affected by chronic HBV infection $[2,3]$. Although viral hepatitis is a significant public health problem globally, it has not

\footnotetext{
*Correspondence: busayo.ajuwon@anu.edu.au

${ }^{1}$ Research School of Population Health, ANU College of Health

and Medicine, The Australian National University, Acton, ACT, Australia

Full list of author information is available at the end of the article
}

been prioritised until recently. In 2016, the World Health Organisation (WHO) adopted the Global health sector strategy on viral hepatitis, which set the goal of eliminating viral hepatitis as a public health problem by 2030, and specifically for $90 \%$ of infected persons to be diagnosed by 2030 [4]. Similarly, the 67th World Health Assembly of the WHO on viral hepatitis prevention and control recently reaffirmed the importance of monitoring viral hepatitis prevention, diagnosis, and treatment progress both nationally and globally [5].

In Africa, approximately 60 million people live with chronic HBV infection with an estimated prevalence of $6.2 \%$ [6]. New infection rates are highest among children, 
and transmission predominantly occurs via perinatal routes. The global prevalence of chronic HBV infection among children under five years declined from $5 \%$ in the pre-vaccine era (1980s to early 2000 s) to less than $1 \%$ in 2019. [1, 7]. Vaccination to protect against HBV infection is part of the WHO Extended Programme for Immunisation (EPI) and has been progressively rolled out across Africa since 1995, alongside enhanced interventions for the prevention of mother to child transmission. Despite more than two decades of vaccine introduction which has been critical for reducing infections in children, the overall population prevalence of HBV infection remains high across many settings in SSA $(>8 \%)[1,8,9]$. Early epidemiological studies have suggested a high variation in the estimates of HBV prevalence between countries and subgroups of the population in SSA. These variations are often explained by methodological differences $[10$, $11]$.

In Africa, Nigeria is ranked as one of the countries that is hyper-endemic for HBV infection (> 8\%) [12]. Approximately nine in ten Nigerians who live with chronic HBV are unaware of their infection status, and are missing from the global public health statistics due to a lack of resources, awareness, and political will for addressing Nigeria's HBV plight [13-15]. Consequently, Nigeria has one of the highest rates of HBV-attributable cancer in West Africa, with an age-standardised incidence estimate of 2.6 to $<5.1$ cases per 100,000 person-years $[16,17]$. $\mathrm{HCC}$ is a highly aggressive cancer with limited treatment options, often lacking in resource-constrained settings [18]. The lack of affordable diagnostics-for example specialised immunoassays and nucleic acid tests, as well as the out-of-pocket cost for vulnerable populations, constitute potential barriers to eliminating viral hepatitis $B$ in Nigeria, thus making HBV a significant threat to public health. Further, clinical and epidemiological research on HBV infection in Nigeria are developing, but have not been able to attract appropriate funding and investment.

There are no up-to-date country-wide systematic reviews reporting HBV prevalence in Nigeria. The first systematic review and meta-analysis of HBV in Nigeria was conducted in 2013 [19] and included $61 \%$ of articles published before 2010. Further, the systematic review conducted by Schweitzer et al. [8] on the estimations of the worldwide prevalence of chronic HBV infection was limited in scope, since the study did not provide detailed information on the sources of data for each country; the review only estimated the prevalence without emphasis on at-risk sub-groups and specific populations to which interventions should be mostly directed. These limitations suggest a research gap that requires an up-to-date comprehensive investigation. To address this, we conducted a systematic review to estimate the prevalence of
HBV in the Nigerian population. Updated national and sub-national data are also needed to design targeted control and prevention strategies to HBV infections.

\section{Methods \\ Study setting}

Nigeria is a densely populated country in Africa, with a population density of 226 people per $\mathrm{km}^{2}$. It has the largest population in Africa, with approximately 206 million people in an area of $923,679 \mathrm{~km}^{2}$, and is located in West Africa on the Gulf of Guinea, between Benin and Cameroon [20,21]. Nigeria is a federation of 36 states and the Federal Capital Territory, grouped into six geopolitical zones. Nigeria's economy is the largest in Africa, with nominal GDP and purchasing power parity of $\$ 450$ billion and $\$ 1$ trillion, respectively. However, its Human Development Index ranks 158th globally, and the country is classified as a lower-middle-income economy, with a gross national income per capita between $\$ 1036$ and $\$ 4045$ [22]. The total healthcare expenditure was estimated at $\$ 18.3$ billion in 2014 , and the primary source has been out-of-pocket expenditure, constituting about $70.3 \%$ of the total healthcare expenditure in 2009 [23]. The expenditure of the Government as a percentage of GDP is below the average for sub-Saharan Africa. Less than $5 \%$ of Nigerians have health insurance coverage, as most enrolees are in the formal sector with very poor coverage in the informal sector [24].

\section{Protocol registration}

The study protocol was prospectively registered in the international prospective register of systematic review, PROSPERO (CRD42020161456). The conduct and reporting of this systematic review and meta-analysis have been guided by the Preferred Reporting Items for Systematic Reviews and Meta-Analyses (PRISMA; Additional file 1) [25].

\section{Search strategy}

We conducted a search of previous systematic reviews and protocols related to the topic of interest using PROSPERO database and database of abstracts of review of effects (DARE) (https://www.inahta.org/hta-database/) to confirm a similar study had not been previously registered and published. A comprehensive search of relevant peer-reviewed articles published between January 1, 2010 and December 31, 2019, was conducted in PubMed, Google Scholar and African Index Medicus. We consulted an expert generalist librarian to develop a search strategy using medical subject headings (MeSH) terms, Boolean functions (AND, OR) and keywords related to HBV and prevalence (Additional file 2). Following an initial search string in PubMed, search strategies 
were adapted for each database. No language limits were applied. Articles were also identified by snow-balling through references of included full-text studies. We used Endnote X9 to catalogue publications and manage references.

\section{Inclusion and exclusion criteria}

Studies that reported the prevalence of HBV in different regions of Nigeria using valid HBV tests were included in this systematic review. Valid HBV tests detect viral proteins (antigens), the antibodies that are produced in response to an infection, or detect the genetic material (DNA) of the virus. The searches were limited by publication year from 2010, in order to specifically focus on studies conducted in the last decade- a decade that succeeded the introduction of HBV vaccine to Nigeria. Further, Musa had earlier conducted a meta-analysis of data published between 2000 and 2013, with $61 \%$ of the data included collected prior to 2010 [14]. Systematic reviews or meta-analyses, case studies, surveillance reports, conference abstracts, animal studies, or studies that did not contain HBV prevalence data were not included in the study.

\section{Study selection and screening}

We used Covidence, a software for the management of systematic reviews [26] to screen for articles, remove duplicates and streamline the process of study selection. Two reviewers (BIA and IY) independently screened the titles and abstract, and conducted a full-text review of articles that appeared to meet the inclusion criteria. Disagreements were resolved through mutual consensus, or if required, with consultation with the senior author (BAL).

\section{Data extraction}

A data extraction form was piloted and fields were refined in consultation with several authors (BIA, IY, KR, AR, BAL). Data extraction fields included standard information such as, general study descriptors (year of publication, region, setting, study design), population characteristics (study group, age), and the number of HBV positive cases, the participant sample size, and the method of diagnosis. Data were extracted independently using a Microsoft Excel Sheet (version 16). Author BIA and IY extracted data from all articles. The senior author was consulted to resolve any differences.

\section{Quality assessment}

We used the Joanna Briggs Institute checklist for prevalence studies to critically appraise [27] the overall methodological quality of included studies. The critical appraisal tool included nine parameters which had yes, no, unclear and not applicable options. The parameters evaluated were: appropriateness of the sampling frame, proper sampling technique, adequacy of sample size, study subject and setting description, sufficient data analysis, use of valid methods for the identified conditions, measurement of the condition in a standard and reliable way, the appropriateness of statistical analysis, and the adequacy of the response rate (Additional file 3). A score of 1 was assigned for a 'yes' response and 0 was assigned for 'no' and 'unclear' responses. The mean score was computed for each study. Two reviewers (BIA and IY) independently conducted the quality assessment, and disagreements were resolved by consensus.

\section{Data analysis}

We analysed meta-data using the metafor package of the statistical software R-version 4.0.2 [28]. Prevalence was defined as the rate of positive assays for HBV. Data were pooled within a random effects model, and a test for heterogeneity was evaluated by the $x^{2}$ test on Cochrane's $Q$ statistic [29], quantified by $\mathrm{I}^{2}$ value. The $\mathrm{I}^{2}$ statistic estimates the percentage of total variation across studies due to true between-study differences rather than chance. The degree of heterogeneity is classified to three levels (minimal, $\mathrm{I}^{2}<25 \%$; moderate, $25 \% \leq \mathrm{I}^{2}<50 \%$; substantial, and $\mathrm{I}^{2} \geq 50 \%$ ) [30]. When substantial heterogeneity is detected, a random effects model is recommended for estimating HBV pooled prevalence at $95 \% \mathrm{CI}$ instead of a fixed-effects model [31]. We assessed the sources of variation among studies with sub-group analysis using the following grouping variables: year of publication, study group, age, region, setting, method of diagnosis, and methodological quality. Publication bias was evaluated using funnel plot asymmetry and the Egger's test [32]. $p$-value $<0.05$ on the Egger's test was considered indicative of statistically significant publication bias. Cohen's kappa coefficient (k) was calculated to see if there was inter-rater agreement between the two reviewers (BA and IY) in abstract screening and methodological quality assessment.

We used the ESRI package in ArcGIS to map the geographical locations of included studies and the regional prevalence of HBV in Nigeria [33].

\section{Results}

\section{Study selection}

PRISMA flow chart for study selection is presented in Fig. 1. We identified 522 records from the three databases including 248 from PubMed, 33 from African Index Medicus and 241 from Google Scholar. An additional eight studies were identified from screening the bibliography of eligible studies. A total of 47 studies met the inclusion criteria and were included in the systematic review and meta-analysis. A substantial inter-rater 


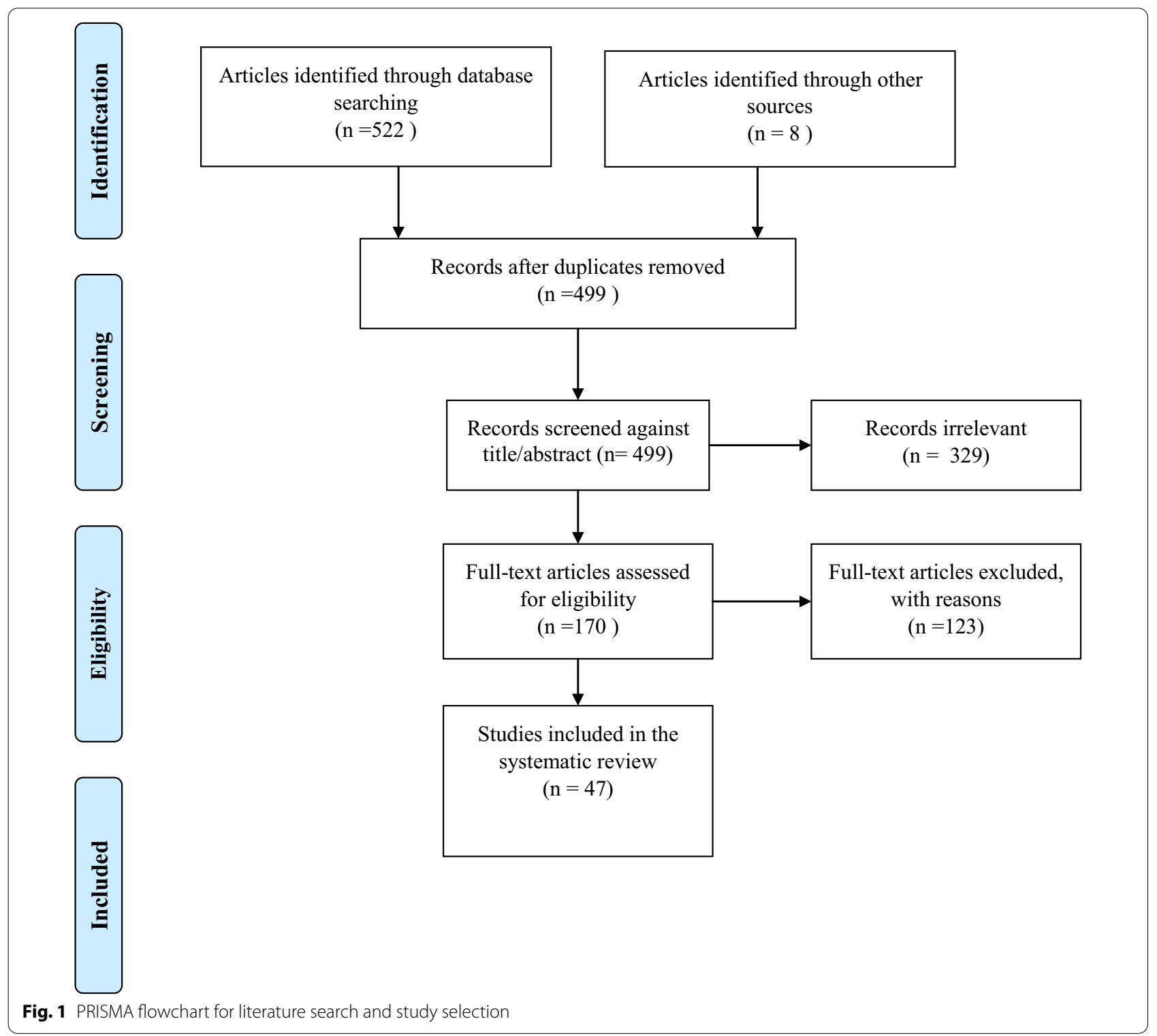

agreement between reviewers (BAL, IY) was observed in abstract screening $\mathrm{k}=76.8 ; p<0.01$. The $p$-value suggests that the appraiser agreement is significantly different to what would be achieved by chance.

\section{Characteristics of included studies}

A total of 21,702 subjects were covered by the 47 studies, with the sample size in individual studies ranging from 93 to 2391, a median of 300 and mean of 461.7. There was a wide variation of HBV prevalence among included studies, ranging from 1 to $28.4 \%$.

The age range of the enrolled subjects was provided by $87.2 \%$ of the studies with the widest age tranche being 1.4-67 years while the narrowest was 5-12 years.
Many studies did not report the mean or median age of the sample. But for the purpose of the analyses, we grouped participants into two distinct age categories, namely, children $\leq 17$ and adult $>17$, based on the premise that $\mathrm{HBV}$ vaccination was introduced to Nigeria in 2004. The age distribution of the studies included $6 / 47(12.8 \%)$ studies in children, $12 / 47$ (25.5\%) studies in adult, and 23/47 (48.9\%) studies in both children and adult. However, $6 / 47$ studies (12.8\%) did not report any age data.

Four (8.5\%) studies were conducted amongst blood donors, $7 / 47(14.9 \%)$ studies amongst HIV positive individuals and 2/47 (4.3\%) amongst HIV positive pregnant women. The majority of the studies $17 / 47$ (36.1\%) 
involved the general population, and pregnant women $17 / 47$ (36.1\%).

The earliest study was conducted in 2010 and the latest in 2019 (Table 1). The number of articles published increased nearly two-fold from 18 (38.3\%) during the 2010-2014 publication period to 29 (61.7\%) from 2015 to 2019. Many studies did not report sex-disaggregated data, hence there was no sufficient information available to stratify the gender profile.

The included studies captured the six geo-political zones of Nigeria. Of these, two studies had a nationwide and inter-regional coverage. The regional locations of the studies included 10/47 (21.3\%) studies in the North Central zone, 1/47 (2.1\%) study in the North East zone, $7 / 47$ (14.9\%) studies in the North West zone, 6/47 (12.8\%) studies in the South East zone, 6/47 (12.8\%) studies in the South South, 15/47 (31.9\%) studies in the South West zone, and $2 / 47$ (4.3\%) studies with a mixed coverage. Another 4/47 (8.5\%) studies were conducted in rural populations, $31 / 47(66.0 \%)$ in urban populations and $12 / 47$ (25.5\%) in mixed populations. The regional prevalence of HBV is shown in Fig. 2.

Examining the methods of diagnoses used for detecting HBV, 21/47 (44.7\%) studies used enzyme-linked immunosorbent assay (ELISA). Rapid diagnostic test (RDT) was used in 20/47 (42.5\%) studies, while polymerase chain reaction (PCR) was used in only one study $(2.1 \%)$.

\section{Methodological quality of included studies}

The studies scored median of 6 (range 4-8) using JBI's nine items of risk bias (Additional file 4). Five (10.6\%) studies had a quality score of $8,38 / 47$ (80.9\%) studies scored between 5 and 7 , and $4 / 47(8.5 \%)$ studies had a quality score of 4 . All studies used valid diagnostic methods for HBV detection and the prevalence was measured in a standardised way. An almost perfect inter-rater agreement of $\mathrm{k}=84.9 \%$; $<0.01$ was observed between the two reviewers (BA and IY).

\section{Prevalence of HBV infection in Nigeria}

The pooled prevalence of HBV infection was 9.5\% (95\% CI 8.1-11.0), with heterogeneity index $\left(I^{2}\right)$ of $91.2 \%$ $(p<0.01)$ (Fig. 3), confirming substantial heterogeneity across studies.

\section{Subgroup analysis of HBV prevalence}

The results of the sub-group analysis of the pooled prevalence, including assessment of differences between subgroups, are presented in Table 2. Geographically, the North West Zone had the highest prevalence $(12.1 \%$, 95\% CI 7.2-19.6) while the South East Zone had the lowest prevalence (5.9\%, 95\% CI 3.8-9.2). In the studies providing age-specific estimates, the prevalence was higher in adults $(12.7 \%$, 95\% CI 8.4-18.8) than in children (11.4\%, 95\% CI 7.5-17.1). Studies conducted on blood donors accounted for the highest prevalence (13.2\%, 95\% CI 9.7$17.8)$ followed by other general population $(10.8 \%$, $95 \%$ CI $8.6-13.5)$ and HIV positive individuals $(9.9 \%, 95 \% \mathrm{CI}$ 6.7-14.4). Subgroup analysis by publication year revealed an apparent downward trend in prevalence from 2010 to $2014(10.1 \%, 95 \%$ CI $7.9-13.0)$ to $2015-2019$ group (9.0\%, 95\% CI 7.4-11.0). Further, studies conducted in urban areas showed lower prevalence $(8.2 \%, 95 \%$ CI $6.9-$ 9.9) than studies conducted in rural areas $(10.7 \%$, $95 \%$ CI 5.01-21.4). In reference to the methods of diagnosis, studies conducted using PCR accounted for the least prevalence estimate $(8.3 \%, 95 \%$ CI 5.1-13.4). A relatively large degree of heterogeneity was identified across most estimates. Setting $(p=0.008)$ and region $(p=0.005)$ were significantly associated with the pooled prevalence heterogeneity $(p<0.05)$.

\section{Publication bias}

The Egger's regression test was not statistically significant $(\mathrm{p}=0.879)$. We found no evidence of publication bias, as supported by the funnel plot (Fig. 4).

\section{Discussion}

In this meta-analysis, we set out to determine the pooled prevalence of $\mathrm{HBV}$ in the Nigerian population. Our analysis shows that HBV prevalence is high, as per the World Health Organisation's criteria for HBV endemicity, $(\geq 8 \%$; high, 2-7\%; moderate and $<2 \%$; low) [34]. Findings of this study provide a critical data to assess the impact of current prevention and control strategies in Nigeria, and serve as a reference for designing and implementing effective public health management programmes towards the 2030 elimination goal.

Nigeria's overall pooled prevalence of $\mathrm{HBV} 9.5 \%$ is similar to that of Cameroon 11.2\% [35] and Burkina Faso $11.2 \%$ [36] but greater than that of Ethiopia 6\% [37]. The United Nations estimates that Nigeria's population in 2021 is 211.4 million [38]. Applying the $9.5 \%$ prevalence to this figure translates into 20.083 million people who had HBV. Somehow, these millions have been missing in the public health space, not only in Nigeria but also in the global public health agenda [39]. Until recently when the WHO set the 2030 elimination goal for viral hepatitis, HIV/AIDS which affects an estimated 1.9 million persons in Nigeria [40] had been receiving more public health priority. In Nigeria, the burden of viral hepatitis B requires continued improvement of screening, broader access to treatment and the integration of prevention and care in local healthcare systems. The WHO's ambitious goal to eliminate viral hepatitis by 2030 may not come 


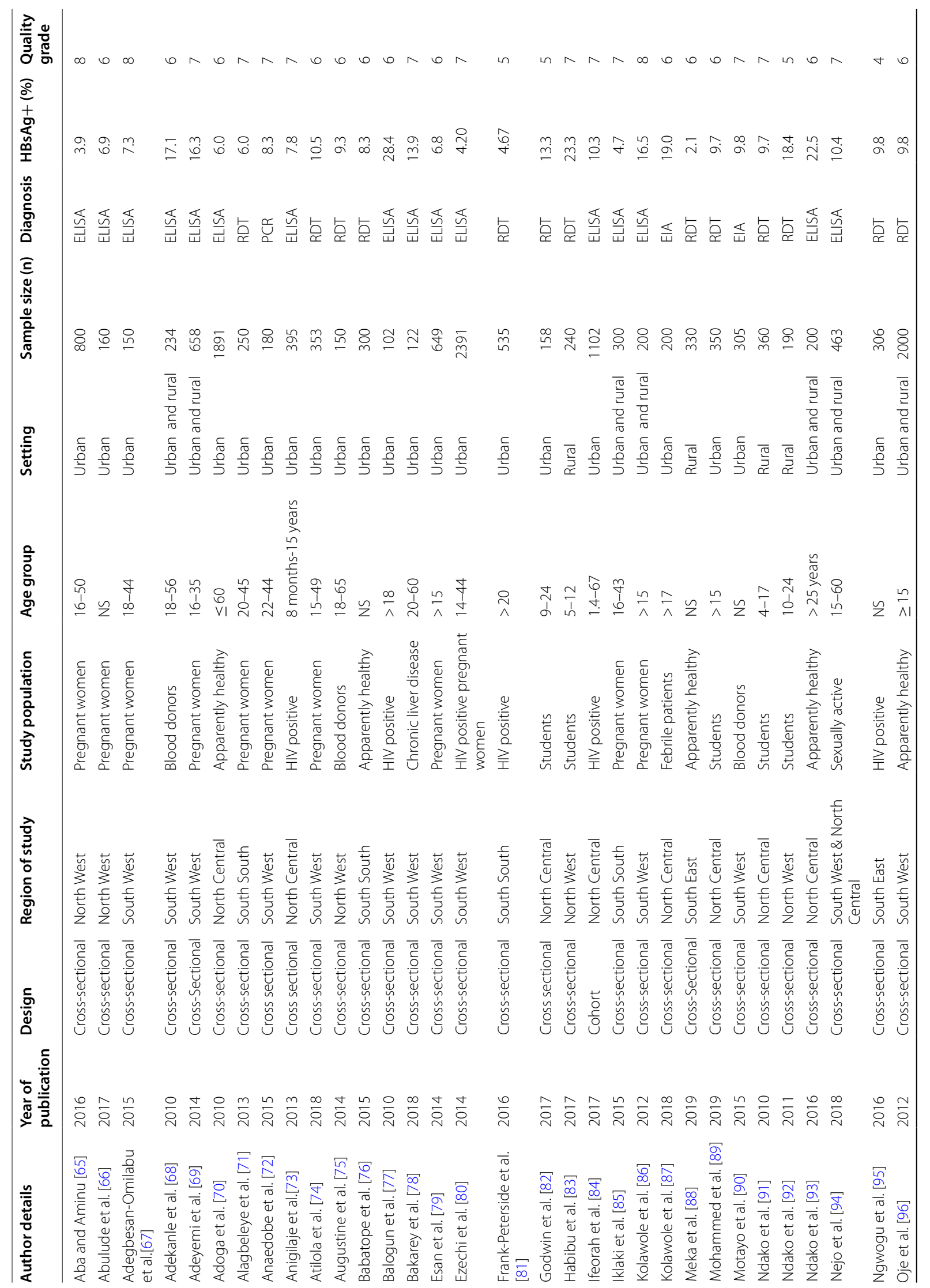




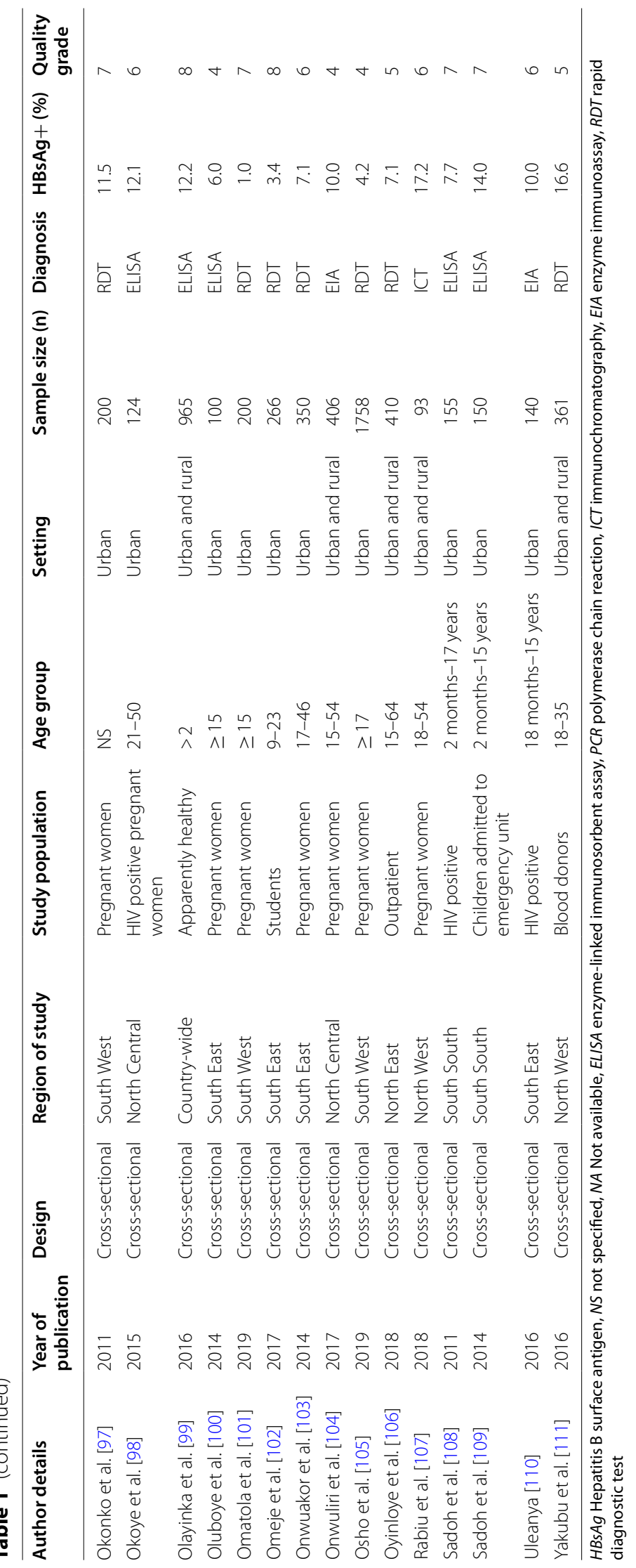




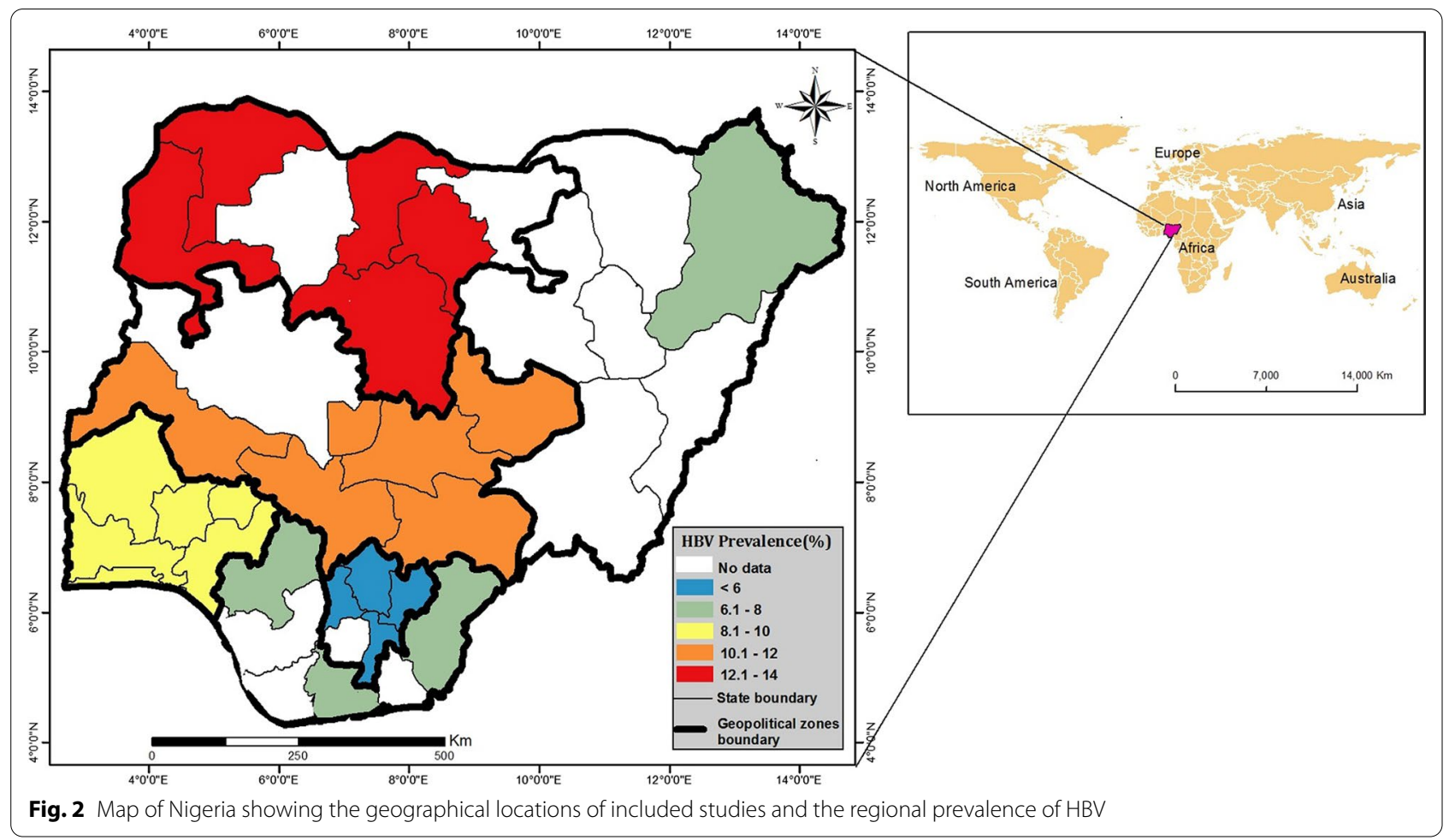

into fruition if the trends in healthcare system are not realigned towards universal care in the face of this high prevalence.

The pooled prevalence estimates of HBV among pregnant women accounted for $7.7 \%$. In Burkina Faso, a prevalence of $11.2 \%$ [36] was obtained among pregnant women. Jean et al. [35] and Ofori-Asenso et al. [41] also obtained a prevalence of $11.1 \%$ and $13.1 \%$ among pregnant women in Cameroon and Ghana, respectively. Though, the obtained prevalence for pregnant women in this study is lower than the aforementioned countries, it is higher than the prevalence in Ethiopia 5.0\% [42], Rwanda 3.1\% [43] and Tanzania 5.2\% [44]. The prevalence in the sub-population of pregnant women in Nigeria has serious implications, including the risk of perinatal transmission of HBV infection and accelerated HBV-related liver disease. Robust pre-conception screening and the implementation of 'test and treat' interventions at low cost for infected couples can bolster the existing policy on the prevention of vertical transmission of HBV. In addition, timely birth dose vaccination of newborn infants is critical to provide the earliest possible protection to future birth cohorts and reduce the pool of chronic HBV carriers in the population.

HBV prevalence among patients with HIV was estimated to be $9.9 \%$, although this rate is lower than the $12.5 \%$ reported in a study by Hamza et al. [45], and the $11.5 \%$ prevalence obtained from a health facility in North central Nigeria [46]. This prevalence is higher than the WHO's threshold for high-endemic areas. Additionally, this study revealed a prevalence of $7.0 \%$ among HIV positive pregnant women. These results suggest that the burden of HBV and HIV co-infection is significant in the Nigerian population, and may lead to higher levels of detectable virus [47], accelerated cirrhosis [48] and increased likelihood of developing HCC [49] in the already immune-compromised sub-population. The dynamics and epidemiology of HBV infection is distinct in HIV patients, and continuing to target these individuals with the implementation of HBV screening remains very pertinent.

HBV prevalence among blood donors was estimated to be $13.2 \%$, although this estimate is lower than the $14.0 \%$ reported in a previous systematic review by Musa et al. [19]. This result raises significant concern regarding the safety of blood and blood products in Nigeria, as nearly 1 in 8 blood donors may be infected with HBV. Our results further showed that ELISA and RDTs were the most frequently used diagnostics in the Nigerian population, including blood donors. This could be attributed to their relative ease of use and lower cost. Meanwhile, the less than $60 \%$ sensitivity reported for RDTs, and the inability of ELISA to detect certain HBV mutant strains have raised serious concerns for their use in blood donation centres [50]. This emphasises the need for robust screening techniques and strict adherence to the national blood 


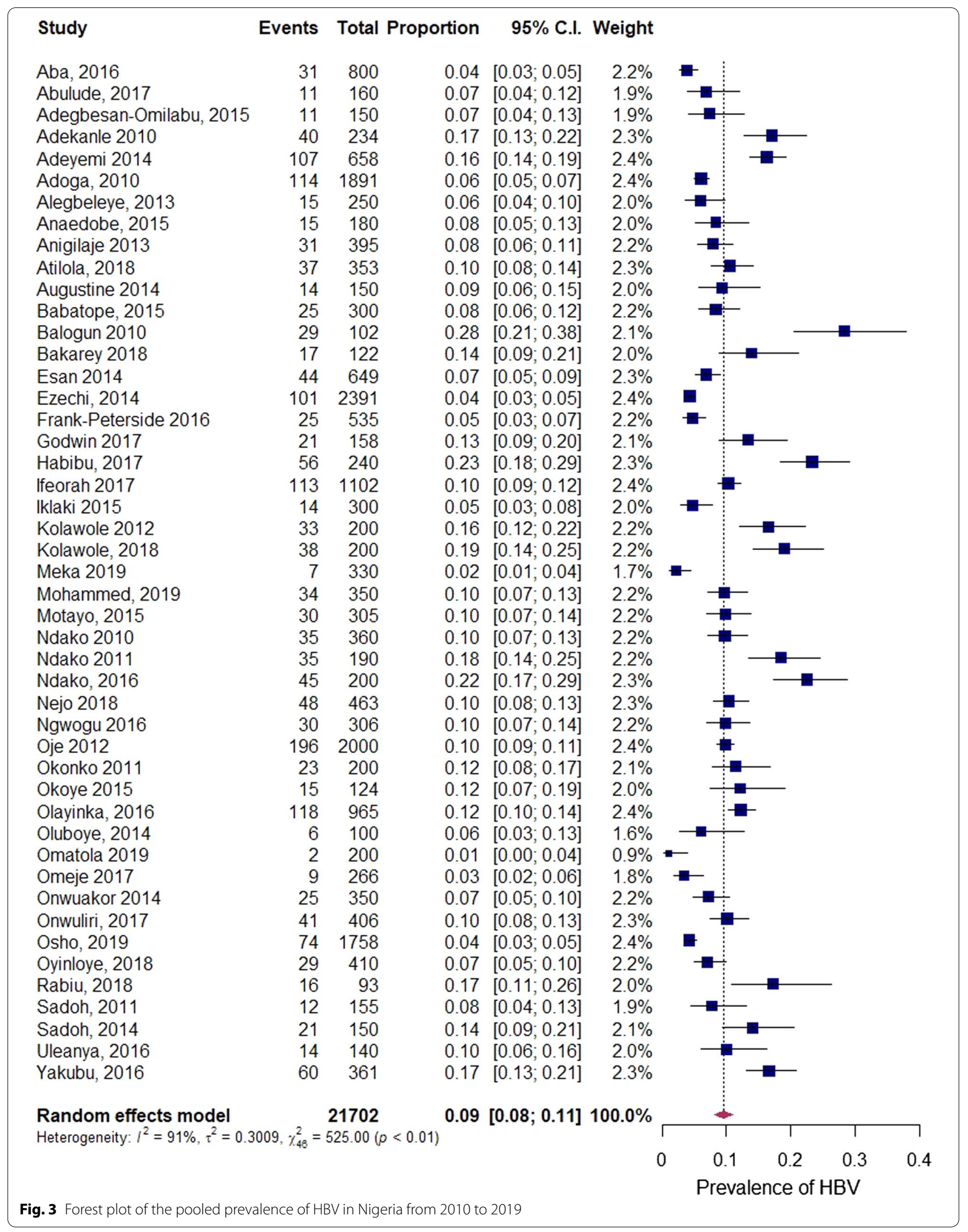


Table 2 Sub-group analysis of the pooled prevalence of hepatitis B infection in Nigeria

\begin{tabular}{|c|c|c|c|c|c|c|}
\hline Sub-group variables & Variable category & $\begin{array}{l}\text { Included } \\
\text { studies }\end{array}$ & Prevalence $\%(95 \% \mathrm{CI})$ & $\mathrm{I}^{2} \%$ & $p$-heterogeneity & $p$-difference \\
\hline \multirow[t]{5}{*}{ Study group } & Blood donor & 4 & $13.2(9.7-17.8)$ & 72.5 & 0.012 & 0.129 \\
\hline & Pregnant women & 17 & $7.7(5.8-10.2)$ & 90.1 & $p<0.001$ & \\
\hline & HIV positive & 7 & $9.9(6.7-14.4)$ & 88.6 & $p<0.001$ & \\
\hline & HIV positive pregnant women & 2 & $7.0(2.4-18.7)$ & 93.3 & $p<0.001$ & \\
\hline & Others & 17 & $10.8(8.6-13.5)$ & 91.1 & $p<0.001$ & \\
\hline \multirow[t]{2}{*}{ Mean methodological quality } & $J \mathrm{Bl} \leq 6$ & 9 & $9.1(6.0-13.4)$ & 92.7 & $p<0.001$ & 0.795 \\
\hline & $\mathrm{JBI}>6$ & 38 & $9.6(8.1-11.3)$ & 91.0 & $p<0.001$ & \\
\hline \multirow[t]{7}{*}{ Region/zone } & North West & 7 & $12.1(7.2-19.6)$ & 93.3 & $p<0.001$ & 0.005 \\
\hline & North East & 1 & $7.1(5.0-10.0)$ & NA & 1.0 & \\
\hline & South West & 15 & $9.7(7.1-13.1)$ & 94.3 & $p<0.001$ & \\
\hline & South East & 6 & $5.9(3.8-9.2)$ & 76.7 & $p<0.001$ & \\
\hline & South South & 6 & $7.1(4.9-10.0)$ & 73.6 & 0.002 & \\
\hline & North Central & 10 & $11.2(8.5-14.7)$ & 89.6 & $p<0.001$ & \\
\hline & Mixed & 2 & $11.6(10.0-13.5)$ & 5.0 & 0.305 & \\
\hline \multirow[t]{2}{*}{ Year of publication } & 2010-2014 & 18 & $10.1(7.9-13.0)$ & 92.6 & $p<0.001$ & 0.467 \\
\hline & 2015-2019 & 29 & $9.0(7.4-11.0)$ & 90.4 & $p<0.001$ & \\
\hline \multirow[t]{5}{*}{ Method of diagnosis } & ELISA & 21 & $10.0(7.8-12.6)$ & 93.2 & $p<0.001$ & 0.066 \\
\hline & $\mathrm{RDT}$ & 20 & $8.4(6.5-10.6)$ & 90.7 & $p<0.001$ & \\
\hline & PCR & 1 & $8.3(5.1-13.4)$ & NA & NA & \\
\hline & EIA & 4 & $11.9(8.4-16.7)$ & 75.6 & 0.006 & \\
\hline & $\mathrm{ICT}$ & 1 & $17.2(10.81-26.3)$ & NA & NA & \\
\hline \multirow[t]{3}{*}{ Setting } & Rural & 4 & $10.7(5.01-21.4)$ & 94.3 & $p<0.001$ & 0.008 \\
\hline & Urban & 31 & $8.2(6.9-9.9)$ & 88.0 & $p<0.001$ & \\
\hline & Mixed & 12 & $12.6(10.3-15.3)$ & 86.9 & $p<0.001$ & \\
\hline \multirow[t]{4}{*}{ Age } & $\leq 17$ & 6 & $11.4(7.5-17.1)$ & 87.2 & $p<0.001$ & 0.140 \\
\hline & $>17$ & 12 & $12.7(8.4-18.8)$ & 94.2 & $p<0.001$ & \\
\hline & Mixed & 23 & $8.2(6.8-10.0)$ & 90.8 & $p<0.001$ & \\
\hline & Not stated & 6 & $7.8(5.5-10.9)$ & 73.2 & 0.002 & \\
\hline
\end{tabular}

ELISA enzyme-linked immunosorbent assay, PCR polymerase chain reaction, ICT immunochromatography, EIA enzyme immunoassay, RDT rapid diagnostic test

transfusion policy in Nigeria, which requires the screening of all donated blood for transfusion-transmissible infections including HIV, HBV, HCV and syphilis [51].

As revealed by this study, we found region-specific differences in prevalence estimates. The highest $12.1 \%$ and the least prevalence $5.9 \%$ were obtained from the North West and South East geo-political zones, respectively. This is consistent with patterns previously described in literature, with the potential for marked differences in prevalence, even between neighbouring states [52]. A diverse range of factors influence the observed variations in HBV prevalence across Nigeria, with significant inequities in birth dose vaccination, among the most widely recognised. The immunisation coverage of birth dose varied widely across Nigeria, from the highest coverage of $64.9 \%$ in South East to the lowest coverage of $14.1 \%$ in North West [53]. Multiple barriers have been identified for the low birth dose uptake in North West region [54], including relative geographical isolation, religious beliefs that fuel vaccine hesitancy, limited antenatal screening for HBV surface antigen, birth occurring outside healthcare facilities, and lack of skilled medical staff to provide birth-dose vaccination.

Of particular interest from our findings is the ruralurban difference in the prevalence of HBV. We obtained a prevalence of $10.7 \%$ in rural setting, compared with $8.2 \%$ in urban setting. This indicates that HBV is most prevalent in rural areas of Nigeria, and may have been intensified by the lack of awareness about the implications of HBV infection, under-developed shared care pathways for HBV management, and high-risk lifestyles that characterise the countryside. This result suggests the need to develop trust and ensure culturally appropriate strategies when delivering care for HBV in rural settings.

When stratified by age, the prevalence estimate was $12.7 \%$ in the age group $>17$, namely, those born before 2004 , then decreased to $11.4 \%$ in the age group $\leq 17$. While this was not significant noting the overlapping 


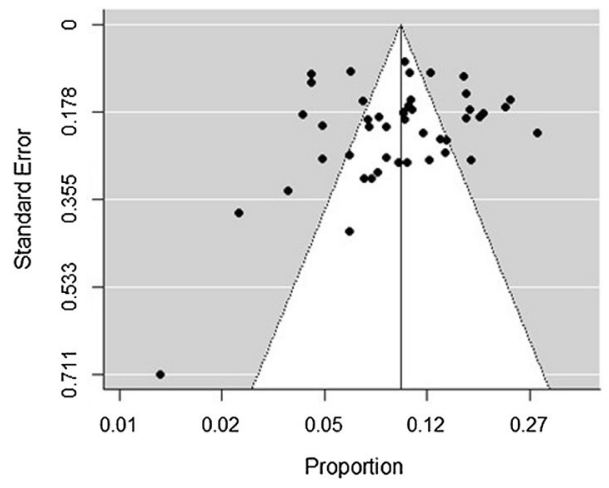

Fig. 4 Bias assessment funnel plot of studies reporting HBV prevalence in Nigeria from 2010 to 2019

confidence intervals and $p$ of 0.140 , it is worth noting that these are individuals born from 2004 upwards, the year which marked the implementation of the universal HBV immunisation programme in Nigeria. The observed decline in prevalence may reflect the increase in HBV vaccination coverage among children. UNICEF reported HBV vaccination coverage was $0 \%$ in $2000-2005,18 \%$ in 2006 [55], and 41\% in 2013 [19]. However, there was a significant drop in vaccination coverage from $41 \%$ in 2013 to $30.2 \%$ in 2016/2017 [53]. Despite the reduced coverage level, the importance of infant vaccination remains very paramount, as validated in clinical practice and population epidemiology across diverse settings.

Further, the observed prevalence in the children agegroup presents an evidence of a continued acquisition of HBV infection in the vaccine-eligible population. Beyond low vaccination coverage, the most likely explanation is an incomplete vaccine coverage $[56,57]$. Research has shown that infants who received fewer than the three scheduled hepatitis $B$ vaccine doses are at a higher risk of infection [58, 59]. Inadequate coverage of the full schedule may have contributed to the rate of infection observed in vaccine-eligible child populations in Nigeria. This emphasises the need for Nigeria to take pragmatic measures in meeting the WHO target of $90 \%$ coverage of the hepatitis B vaccine in infancy [60], as low and inadequate coverage are potential contributors to high HBV prevalence.

Unlike hepatitis $C$, there is no therapeutic for hepatitis $B$, but current treatments are well tolerated and effective at preventing liver disease and reducing viral load. It is believed that 9 in 10 Nigerians living with HBV are unaware of their infection status, and therefore at risk of not receiving treatment due to inadequate monitoring for their condition [61]. This profound lack of access to treatment and care among the adult population, with a prevalence of $12.7 \%$ contributes to the disproportionate impact of HBV in Nigeria.

In this study, HBV prevalence appears to be declining over time. This is consistent with global trends [39]. Studies conducted between 2000 and 2013 by Musa et al. [19] recorded the highest prevalence of $14.0 \%$, compared with the lower prevalence estimates of $10.1 \%$ and $9.0 \%$ that we obtained for studies between 2010-2014 and 2015-2019, respectively. These apparent downward trend in prevalence of HBV in Nigeria may in part reflect coverage of the universal HBV vaccination introduced in 2004, and the likely improvements in socio-economic conditions across time-period. The results suggest that to further reduce HBV prevalence in Nigeria, a dedicated focus on socio-economic, cultural and population health factors are required, for example, equity of access across rural and urban regions.

Among methods of diagnosis, PCR accounted for the lowest prevalence estimate of $8.3 \%$, compared with ELISA 10.0\%. This result further suggests that PCR was the least used method of diagnosis in the Nigerian population. This reflects the high-cost implication of PCR. There are relatively few laboratories in Nigeria that possess the capability of performing real-time quantitative PCR for HBV DNA. The cost of this assay is about $\$ 200$ $\$ 250$ per test, and as in many settings, patients have to pay for the test. It also requires time, skilled lab technicians, and sophisticated equipment and laboratories, and the value is used in the algorithm for making decision on who to treat and how to clinically manage the patients, in line with the international criteria for treatment eligibility [62]. Therefore, most infected populations are left without care, since treatment eligibility rely on parameters such as, HBV viral load and liver fibrosis, and these are often difficult to assess routinely in resource-constrained settings.

Also, most rural and remote laboratories do not have access to specialised second-tier assays, such as immunoassays. These limitations have impeded the uptake of HBV screening in the Nigerian population. Consequently, there is an urgent need for alternative diagnostics that assess and/or predict HBV infection, in a way that will improve access to affordable testing for the missing millions who are unaware of their HBV status. For instance, a simple pathology index, the gamma-glutamyl transpeptidase to platelet ratio (GPR) [63] was developed in HBV-monoinfected subjects in The Gambia, with improved performance for the diagnosis of fibrosis and cirrhosis in comparison to liver biopsy, and with the added advantage for remote and rural settings of not requiring invasive biopsy procedures. 


\section{Strength and limitations}

This review and meta-analysis presents the most updated pooled estimate of the prevalence of $\mathrm{HBV}$ in Nigeria. Further, it employed a comprehensive search strategy across three key data sources, and involved a large number of studies and study participants, covering the country's six geopolitical zones. Our estimates were robust and corroborated by the absence of evidence of a publication bias. We also provided the prevalence among age-specific group born before and after the introduction of universal HBV vaccination, to reaffirm the importance of childhood immunisation. This was not investigated by the previous systematic review [19].

Limitations of this systematic review are related to the available data and the substantial heterogeneity across included studies. First, the quality of reporting of studies varied. For instance, many available studies did not report sex-specific prevalence. Further, data available on prevalence in infants were particularly sparse, hence, we could not stratify the available age-banded data to estimate prevalence in under 5 years of age. Second, there was substantial heterogeneity across the included studies, and this may undermine confidence in the pooled estimate. However, we investigated the potential sources of heterogeneity, and results showed that heterogeneity may have been due to the differences in the study setting and region. High levels of heterogeneity appear to be the bane of similar meta-analytic studies on HBV in Africa with reports of $\mathrm{I}^{2}$ statistics of $94-99.9 \%$ [36, 37, 64].

\section{Conclusions}

Our results show that the burden of HBV infection in Nigeria is high, and is unevenly distributed among various sub-populations and geo-political zones. Further studies are required to better understand the extent to which genotype-specific epidemiological factors might influence the regional distribution of HBV prevalence in Nigeria. To promote future research, and subsequent high-quality translation to health settings, we suggest that national guidelines be developed to ensure consistency for data collection across the country, and hence improve the quality of reporting. For example, the routine recording of age and sex, among other relevant population and individual variables, will support deeper insights into the true HBV situation, and lead to tangible improvements for patients and their communities. We also advocate significant investment in capacity building for improving HBV diagnosis, and sustained surveillance to monitor progress towards elimination. A systematic commitment to early diagnosis and clinical management represents a key component of the journey towards HBV elimination by 2030 .

\section{Abbreviations}

HBV: Hepatitis B virus; HCC: Hepatocellular carcinoma; ELISA: Enzyme-linked immunoassay; RDT: Rapid diagnostic test; $\mathrm{PCR}$ : Polymerase chain reaction; $\mathrm{Cl}$ : Confidence interval.

\section{Supplementary Information}

The online version contains supplementary material available at https://doi. org/10.1186/s12879-021-06800-6.

Additional file 1. PRISMA 2009 checklist.

Additional file 2. Pubmed search strategy.

Additional file 3. JBI critical appraisal checklist for studies reporting prevalence data.

Additional file 4. Quality assessment of included studies.

\section{Acknowledgements}

We would like to acknowledge Mr. Abdulraheem Agoro for assistance with the use of ArcGis software

\section{Authors' contributions}

$\mathrm{BIA}$ and BAL conceptualised the work and conducted the literature search. BIA and IY screened the articles, conducted data extraction and assessed the methodological quality of the studies in consultation with BAL. BIA conducted the data analysis in consultation with AR. AR, KR and MS provided content expertise. BIA drafted the manuscript. All authors critically analysed findings, and contributed to the critical review and interpretation of the article. All authors read and approved the final manuscript.

\section{Funding}

BIA is supported by funding from RSTMH Small Grants Programme in Partnership with the National Institute for Health Research (NIHR). AR is partly funded by the Australian National Health and Medical Research Ideas Grant (1184720). MS is funded by a Westpac Research Fellowship. BAL was supported by funding from the Australian Commonwealth Department of Health Quality Use of Pathology Programme (QUPP) funding (4-2UJWED1).

\section{Availability of data and materials}

All data generated or analysed during this study are included in this published article (Table 1).

\section{Declarations}

Ethics approval and consent to participate Not applicable.

\section{Consent for publication}

Not applicable.

\section{Competing interests}

The authors declare that they have no competing interests.

\section{Author details}

${ }^{1}$ Research School of Population Health, ANU College of Health and Medicine, The Australian National University, Acton, ACT, Australia. ${ }^{2}$ Department of Biosciences and Biotechnology, Faculty of Pure and Applied Sciences, Kwara State University, Malete, Nigeria. ${ }^{3}$ Statistical Consulting Unit, The Australian National University, Acton, ACT, Australia. ${ }^{4}$ Department of Health Evidence, Radboud UMC, 6500 HB Nijmegen, The Netherlands.

Received: 24 August 2021 Accepted: 12 October 2021 Published online: 30 October 2021 


\section{References}

1. World Health Organisation. Hepatitis B key facts. 2021. https://www who.int/newsroom/factsheets/detail/hepatitis-b. Accessed 29 Sept 2021

2. Global Burden of Disease Mortality and Causes of Death Collaborators. Global, regional, and national age-sex specific all-cause and cause-specific mortality for 240 causes of death, 1990-2013: a systematic analysis for the Global Burden of Disease Study 2013. Lancet. 2013:385(9963):117-71.

3. Global Burden of Disease Collaborative Network. Global Burden of Disease Study 2010 (GBD 2010) results by cause 1990-2010. Institute for Health Metrics and Evaluation (IHME). http://ghdx.healthdata.org/ record/ihme-data/gbd-2010-results-cause-1990-2010. Accessed 5 Feb 2021.

4. World Health Organisation. Global health sector strategy on viral hepatitis, 2016-2021. 2016. https://apps.who.int/iris/bitstream/handle/10665/246177/WHO-HIV-2016.06eng.pdf?sequence=1. Accessed 27 Jan 2021.

5. World Health Organisation. Hepatitis. Sixty-seventh world health assembly. Agenda item 12.3. May 24, 2014. http://apps.who.int/gb/ ebwha/pdf_files/wha67/a67_r6-en.pdf?ua=1. Accessed 18 Jan 2021.

6. World Health Organisation. Hepatitis B fact sheet. 2019. https://www. who.int/newsroom/factsheets/detail/hepatitis-b. Accessed $21 \mathrm{Mar}$ 2021

7. Indolf G, Easterbrook P, Dusheiko G, Siberry G, Chang MH, Thorne C, et al. Hepatitis B virus infection in children and adolescents. Lancet Gastroenterol Hepatol. 2019;4(6):466-76.

8. Schweitzer A, Horn J, Mikolajczyk RT, Krause G, Ott JJ. Estimations of worldwide prevalence of chronic hepatitis B virus infection: a systematic review of data published between 1965 and 2013. The Lancet. 2015;386(10003):1546-55.

9. Ott JJ, Horn J, Krause G, Mikolajczyk RT. Time trends of chronic HBV infection over prior decades - a global analysis. J Hepatol. 2017;66(1):48-54

10. Jacobs B, Mayaud P, Changalucha J, Todd J, Ka-Gina G, Grosskurth $\mathrm{H}$, et al. Sexual transmission of hepatitis B in Mwanza, Tanzania. Sex Transm Dis. 1997;24(3):121-6.

11. Belo AC. Prevalence of hepatitis B virus markers in surgeons in Lagos, Nigeria. East Afr Med J. 2000;77(5):283-5.

12. Kramvis A, Kew MC. Epidemiology of hepatitis B virus in Africa, its genotypes and clinical associations of genotypes. Hepatol Res. 2007;37(s1):S9-19.

13. The Journey to hepatitis elimination in Nigeria. In: Hepatitis Foundation: media centre. 2020. https://www.hepb.org/blog/journey-hepat itis-elimination-nigeria/. Accessed 29 Sept 2021.

14. Federal Ministry of Health. National AIDS/STIS control program. 2016. https://www.hepb.org/assets/Uploads/Nigeria-Hepatitis-GuidelinesTX-guidelines.pdf. Accessed 29 Sept 2021.

15. World Hepatitis Alliance. Find the missing millions: barriers to diagnosis global report. 2018.

16. International Agency for Research on Cancer. Cancers attributable to infections: age standardized rates (in Africa) per 100000 individuals in 2018 attributable to infections (Hepatitis B virus), by country. https://gco.iarc.fr/causes/infections/tools-map?mode $=1 \&$ sex $=$ $0 \&$ continent $=1$ \&agent $=2 \&$ cancer $=0 \&$ key $=$ asr \&scale $=$ threshold. Accessed 29 Sept 2021

17. de Martel C, Georges D, Bray F, Ferlay J, Clifford GM. Global burden of cancer attributable to infections in 2018: a worldwide incidence analysis. Lancet Glob Health. 2020;8(2):e180-90.

18. Howell J, Lemoine M, Thursz M. Prevention of materno-foetal transmission of hepatitis B in sub-Saharan Africa: the evidence, current practice and future challenges. J Viral Hepatitis. 2014;21(6):381-96.

19. Musa BM, Bussell S, Borodo MM, Samaila AA, Femi OL. Prevalence of hepatitis B virus infection in Nigeria, 2000-2013: a systematic review and meta-analysis. Niger J Clin Pract. 2015;18(2):163-72.

20. Nigeria Population. WorldMeters. https://www.worldometers.info/ world-population/nigeria-population/. Accessed 28 Jan 2021.

21. Central Intelligence Agency. The world factbook: Nigeria. 2020.

22. World bank data help desk. World bank country and lending groups. https://datahelpdesk.worldbank.org/knowledgebase/articles/ 906519-world-bank-country-and-lending-groups. Accessed 20 Jan 2021.

23. Global Burden of Disease Study 2013 Collaborators. Global, regional, and national incidence, prevalence, and years lived with disability for 301 acute and chronic diseases and injuries in 188 countries, 1990-2013: a systematic analysis for the Global Burden of Disease Study 2013. Lancet. 2015;386(9995):743-800.

24. Uzochukwu BS, Ughasoro MD, Etiaba E, Okwuosa C, Envuladu E, Onwujekwe OE. Health care financing in Nigeria: implications for achieving universal health coverage. Niger J Clin Pract. 2015;18(4):437-44.

25. Liberati A, Altman DG, Tetzlaff JMC, Gøtzsche PC, loannidis JP, et al. The PRISMA statement for reporting systematic reviews and meta-analyses of studies that evaluate health care interventions: explanation and elaboration. PLoS Med. 2009;6(7):e1000100.

26. Veritas Health Innovation. Covidence systematic review software. 2018. www.covidence.org. Accessed Dec 2019.

27. Munn Z, Moola S, Lisy K, Riitano D, Tufanaru C. Methodological guidance for systematic reviews of observational epidemiological studies reporting prevalence and cumulative incidence data. Int J Evid Based Healthc. 2015;13(3):147-53.

28. R Core Team: a language and environment for statistical computing. Vienna: R Foundation for Statistical Computing. 2018.

29. Cochrane $\mathrm{G}$. The combination of estimates from different experiments. Biometrics. 1954;10(1):101-29.

30. Higgins J, Thompson S, Deeks J, Altman D. Measuring inconsistency in meta-analysis. BMJ Open. 2003;327(7414):557-60.

31. Borenstein $M$, Hedges $L$, Higgins $P$, Rothstein $H$. Introduction to metaanalysis. Chichester: Wiley; 2011.

32. Egger M, Davey Smith $G$, Schneider M, Minder C. Bias in meta-analysis detected by a simple, graphical test. BMJ. 1997;315(7109):629-34.

33. ESRI. ArcGIS Desktop: Release 10.8. Redlands: Environmental Systems Research Institute; 2020.

34. Ott JJ, Stevens GA, Groeger J, Wiersma ST. Global epidemiology of hepatitis B virus infection: new estimates of age-specific HBsAg seroprevalence and endemicity. Vaccine. 2012;30:2212-9.

35. Bigna JJ, Amougou MA, Asangbeh SL, Kenne AM, Noumegni SRN, Ngo-Malabo ET, et al. Seroprevalence of hepatitis B virus infection in Cameroon: a systematic review and meta-analysis. BMJ Open. 2017;7(6):e015298.

36. Lingani M, Akita T, Ouoba S, Sanou AM, Sugiyama A, Tarnagda Z, et al. High prevalence of hepatitis B infections in Burkina Faso (1996-2017): a systematic review with meta-analysis of epidemiological studies. BMC Public Health. 2018;18(1):551.

37. Yazie TD, Tebeje MG. An updated systematic review and meta-analysis of the prevalence of hepatitis B virus in Ethiopia. BMC Infect Dis. 2019:19(1):917.

38. World Population Dashboard Nigeria. United Nations Population Fund. https://www.unfpa.org/data/world-population/NG. Accessed 3 Mar 2021.

39. World Health Organisation. Global hepatitis report. WHO: Geneva. 2017a. http://apps.who.int/iris/bitstream/handle/10665/255016/97892 41565455-eng.pdf?sequence=1. Accessed 2 Feb 2021.

40. United Nations Programme on HIV/AIDS (UNAIDS). AIDSinfo. https:// aidsinfo.unaids.org/. Accessed 3 Mar 2021.

41. Ofori-Asenso R, Agyeman AA. Hepatitis B in Ghana: a systematic review \& meta-analysis of prevalence studies (1995-2015). BMC Infect Dis. 2016:16:130.

42. Kebede KM, Abateneh DD, Belay AS. Hepatitis B virus infection among pregnant women in Ethiopia: a systematic review and Meta-analysis of prevalence studies. BMC Infect Dis. 2018;18(1):322.

43. Nyamusi MM, Marete OT, Waweru WR. Seroprevalence of hepatitis B among pregnant women in Kigali, Rwanda. Int J Community Med Public Health. 2016;3(11):3096-101.

44. Kapinga DR. Seroprevalence and factors associated with hepatitis $b$ virus infection in pregnant women attending antenatal clinic in Karagwe District Council. Kagera Region: Muhimbili University of Health and Allied Sciences; 2017.

45. Hamza M, Samaila AA, Yakasai AM, Babashani M, Borodo MM, Habib AG. Prevalence of hepatitis $B$ and $C$ virus infections among HIV-infected patients in a tertiary hospital in North-Western Nigeria. Niger J Basic Clin Sci. 2013:10:76-81. 
46. Tremeau-Bravard A, Ogbukagu IC, Ticao CJ, Abubakar JJ. Seroprevalence of hepatitis B and C among HIV-positive population in Abuja, Nigeria. Afr J Health Sci. 2012;12(3):312-7.

47. Gilson RJ, Hawkins AE, Beecham MR, Ross E, Waite J, Briggs M, et al. Interactions between HIV and hepatitis B virus in homosexual men: effects on the natural history of infection. AIDS. 1997;11(5):597-606.

48. Salmon-Ceron D, Lewden C, Morlat P, Bevilacqua S, Jougla E, Bonnet F, et al. Liver disease as a major cause of death among HIV infected patients: role of hepatitis $C$ and $B$ viruses and alcohol. J Hepatol. 2005;42(6):799-805

49. Clifford GM, Rickenbach M, Polesel J, Dal Maso L, Steffen I, Ledergerber $B$, et al. Influence of HIV-related immunodeficiency on the risk of hepatocellular carcinoma. AIDS. 2008;22(16):2135-41.

50. Mutocheluh M, Owusu M, Kwofie TB, Akadigo T, Appau E, Narkwa PW. Risk factors associated with hepatitis B exposure and the reliability of five rapid kits commonly used for screening blood donors in Ghana. BMC Res Notes. 2014;7:873.

51. Nigerian national blood policy. In: National blood transfusion service. Abuja: Federal Ministry of Health. 2006.

52. Umego C, Mboto C, Mbim E, Edet U, George U, Tarh J. Epidemiology of hepatitis B virus infection in South-South, Nigeria: a review. Int STD Res Rev. 2018;7(1):1-17.

53. Nigerian National Immunisation Coverage Survey: National Brief. Federal Ministry of Health. 2016/2017.

54. Ophori EA, Tula MY, Azih AV, Okojie R, Ikpo PE. Current trends of immunization in Nigeria: prospect and challenges. Trop Med Health. 2014;42(2):67-75.

55. GAVI. Country Tailored Approach for Nigeria 2014-2018. 2014

56. Lai MW, Lin TY, Tsao KC, Huang CG, Hsiao MJ, Liang KH, et al. Increased seroprevalence of HBV DNA with mutations in the s gene among individuals greater than 18 years old after complete vaccination. Gastroenterology. 2012;143(2):400-7.

57. Tsukakoshi T, Samuela J, Rafai EV, Rabuatoka U, Honda S, Kamiya Y, et al. Hepatitis B serologic survey and review of immunization records of children, adolescents and adults in Fiji, 2008-2009. Virol J. 2015;12(36):36.

58. World Health Organization. Practices to improve coverage of the hepatitis B birth dose vaccine. Geneva: World Health Organization; 2013.

59. Schillie S, Walker T, Veselsky S, Crowley S, Dusek C, Lazaroff J, et al. Outcomes of infants born to women infected with hepatitis B. Pediatrics. 2015;135(5):e1141-7.

60. World Health Organization. Combating hepatitis B and C to reach elimination by 2030: advocacy brief. Geneva: World Health Organization; 2016.

61. The Journey to hepatitis elimination in Nigeria. In: Hepatitis Foundation: media centre. 2020. https://www.hepb.org/blog/journey-hepatitiselimination-nigeria/. Accessed 28 Mar 2021.

62. World Health Organization. Guidelines for the prevention, care and treatment of persons with chronic hepatitis B infection. Geneva: World Health Organization; 2015

63. Lemoine M, Shimakawa Y, Nayagam S, Khalil M, Suso P, Lloyd J, et al. The gamma-glutamyl transpeptidase to platelet ratio (GPR) predicts significant liver fibrosis and cirrhosis in patients with chronic HBV infection in West Africa. Gut. 2016;65(8):1369-76.

64. Wang H, Men P, Xiao Y, Gao P, Lv M, Yuan Q, et al. Hepatitis B infection in the general population of China: a systematic review and meta-analysis. BMC Infect Dis. 2019;19(1):811.

65. Aba HO, Aminu M. Seroprevalence of hepatitis B virus serological markers among pregnant Nigerian women. Ann Afr Med. 2016;15(1):20-7.

66. Abulude OA, Ahmed I, Sadisu FU. Assessment of hepatitis B viral infection as a predictor of hepatic enzymes and compounds alteration among antenatal patients. Med Sci (Basel). 2017;5(4):24

67. Adegbesan-Omilabu MA, Okunade KS, Gbadegesin A, Olowoselu OF, Oluwole AA, Omilabu SA. Seroprevalence of hepatitis B virus infection among pregnant women at the antenatal booking clinic of a Tertiary Hospital in Lagos Nigeria. Niger J Clin Pract. 2015;18(6):819-23.

68. Adekanle O, Ndububa DA, Ayodeji OO, Paul-Odo B, Folorunso TA. Sexual transmission of the hepatitis $B$ virus among blood donors in a tertiary hospital in Nigeria. Singap Med J. 2010;51(12):944-7.

69. Adeyemi AB, Enabor OO, Ugwu IA, Abraham OA, Bello FA, Olayemi O. Prevalence of antenatal hepatitis $B$ infection in tertiary and non-tertiary health facilities in Ibadan, Nigeria. Niger J Med. 2014;23(3):248-53.
70. Adoga MP, Gyar SD, Pechulano S, Bashayi OD, Emiasegen SE, Zungwe T, et al. Hepatitis B virus infections in apparently healthy urban Nigerians: data from pre-vaccination tests. J Infect Dev Ctries. 2010;4(6):397-400.

71. Alagbeleye JO, Nyengidiki TK, Ikimalo Jl. Maternal and neonatal seroprevalence of hepatitis B surface antigen in a hospital based population in South-South, Nigeria. Int J Med Med Sci. 2013;5(5):241-6.

72. Anaedobe CG, Fowotade A, Omoruyi CE, Bakare RA. Prevalence, sociodemographic features and risk factors of Hepatitis B virus infection among pregnant women in Southwestern Nigeria. Pan Afr Med J. 2015;20:406.

73. Anigilaje EA, Olutola A. Prevalence and clinical and immunoviralogical profile of human immunodeficiency virus-hepatitis B coinfection among children in an antiretroviral therapy programme in Benue State, Nigeria. ISRN Pediatr. 2013. https://doi.org/10.1155/2013/932697.

74. Atilola G, Tomisin O, Randle M, Isaac KO, Odutolu G, Olomu J, et al. Epidemiology of HBV in pregnant women, South West Nigeria. J Epidemiol Glob Health. 2018;8(3-4):115-23.

75. Augustine O, Ismail U, Wase A, Festus O, Osaro E, Hauwa B, et al. Prevalence of transfusion -transmissible hepatitis B infection among blood donors in Sokoto, North Western, Nigeria. J Health Sci Res. 2014;1(14):113-8

76. Babatope IO, Inyang NJ, Imhanrenezor K, Aghahowa A. Seroprevalence of Hepatitis B and C viruses among apparently healthy adults in Ekpoma, Edo State, Nigeria. SVPJ. 2015;1(1):0015-20.

77. Balogun TM, Durojaiye IO, Sagoe A, Emmanuel S. Seroepidemiology of hepatitis-B surface antigenaemia in HIV positive patients. West Afr J Med. 2010;29(3):169-73.

78. Bakarey AS, Jabaru O, Olayiwola O. Seroprevalence of hepatitis B surface antigenemia and viral infectivity among liver cancer patients accessing care at a tertiary health facility in Southwest Nigeria. J Immunoassay Immunochem. 2018:39(2):196-206.

79. Esan AJ, Omisakin CT, Ojo-Bola T, Owoseni MF, Fasakin KA, Ogunleye A. Sero-prevalence of hepatitis $B$ and hepatitis $C$ virue co-infection among pregnant women in Nigeria. Am J Biomed Res. 2014;2(1):11-5.

80. Ezechi OC, Kalejaiye OO, Gab-Okafor CV, Oladele DA, Oke BO, Musa ZA, et al. Sero-prevalence and factors associated with Hepatitis B and C co-infection in pregnant Nigerian women living with HIV infection. Pan Afr Med J. 2014:17:197.

81. Frank-Peterside N, Ayodele MBO. Sero-prevalence of Hepatitis B virus infection among HIV co-infected patients in Port Harcourt, Rivers State, Nigeria. Rep Opin. 2016;8(5):39-43.

82. Godwin H, Johnson H, Fasosin E. Co-infection of Hepatitis B and C surface antigens among secondary school students in Jos-North Local Government Area of Plateau State, Nigeria. PJST. 2017;18(2):318-29.

83. Habibu B, Belonwu R, Ibrahim M. Seroprevalence of hepatitis B Surface antigen among apparently healthy primary school pupils in Batagarawa Local Government area of Katsina State, Nigeria. Niger J Paediatr. 2017:44(3):136

84. Ifeorah IM, Bakarey AS, Adeniji JA, Onyemelukwe FN. Seroprevalence of hepatitis B and delta viruses among HIV-infected population attending anti-retroviral clinic in selected health facilities in Abuja, Nigeria. J Immunoassay Immunochem. 2017;38(6):608-19.

85. Iklaki CU, Emechebe Cl, Ago BU, Njoku CO. Sero-prevalence of Hepatitis $B$ infection and its risk factors among women admitted for delivery in Ucth, Calabar, Nigeria. Br J Med Med Res. 2015. https://doi.org/10.9734/ BJMMR/2015/16397.

86. Kolawole OM, Wahab AA, Adekanle DA, Sibanda T, Okoh Al. Seroprevalence of hepatitis B surface antigenemia and its effects on hematological parameters in pregnant women in Osogbo, Nigeria. Virol J. 2012;9(317):317.

87. Kolawole OM, Kana SN. Hepatitis B virus and malaria co-infection causing significant changes in hematological and liver function indices in a cohort of subjects in Ilorin, Nigeria. Int J Infect. 2018;5(3):e81528.

88. Meka IA, Onodugo OD, Obienu O, Okite J. Hepatitis B surface antigenemia in two rural communities in Enugu, Nigeria. Niger J Clin Pract. 2019:22(7):932-5

89. Mohammed HI, Pennap GR, Oti VB, Adoga MP. Markers of hepatitis B virus infection in a subset of young people in central Nigeria. Sci Afr. 2019;5:e00121.

90. Motayo BO, Akpa OM, Ezeani I, Faneye AO, Udo UA, Onoja B. Seroprevalence rates of hepatitis $C$ virus (HCV) antibody and hepatitis $B$ virus 
surface antigen ( $\mathrm{HBsAG}$ ) in blood donors in a Southwestern Nigerian city. J Immunoassay Immunochem. 2015;36(1):91-9.

91. Ndako JA, Echeonwu GON, Olabode AO, Nwankiti OO, Aimakhu SO, Onovoh EM, et al. Seroprevalence of hepatitis B surface antigen ( $\mathrm{HBsAg}$ ) among children of primary school age in a community, North-Central, Nigeria. Sierra Leone J Biomed Res. 2010;2(1):32-7.

92. Ndako JA, Nwankiti OO, Echeonwu GN, Junaid SA, Anaele O, Anthony TJ. Studies on prevalence and risk factors for Hepatitis B Surface Antigen among secondary school students in north-central, Nigeria. Sierra Leone J Biomed Res. 2011;3(3):163-8.

93. Ndako JA, Onwuliri FC, Banda JM, Alejolowo OO, Fajobi V, Olapade DO Risk factors and prevalence of Hepatitis B Surface Antigen ( $\mathrm{HBsAg}$ ) among apparently healthy volunteers in an urban setting, North-Central Nigeria. Int J Sci. 2016;5(3):9-15.

94. Nejo Y, Faneye AO, Olusola B, Bakarey S, Olayinka A, Motayo B, et al. Hepatitis $B$ virus infection among sexually active individuals in Nigeria: a cross-sectional study. Pan Afr Med J. 2018;30:155.

95. Ngwogu KO, Onyemachi PEN, Nwogwu AC. Seroprevalence of hepatitis B surface antigenemia among HIV-infected individuals in Aba, South Eastern Nigeria. IJCR. 2016;5(4):143-50

96. Oje OJ, Sule WF, Famurewa D. Dual positivity of hepatitis B surface antigen and anti-hepatitis $C$ virus antibody and associated factors among apparently healthy patients of Ekiti State, Nigeria. Viral Immunol. 2012:25(6):448-55.

97. Okonko IO, Udeze AO. Detection of Hepatits B surface Antigen ( $\mathrm{HBsAg}$ ) among pregnant women attending Antenatal Clinic at O.L.A. Catholic Hospital, Oluyoro, Ibadan, Oyo State Southwestern Nigeria. Nat Sci. 2011;9(11):54-60.

98. Okoye F, Anzaku A, Ocheke A, Musa J, Sagay A. Burden and determinants of Hepatitis B Virus co-infection in a cohort of HIV positive pregnant women in Jos, Nigeria. IJTDH. 2015;9(3):1-9.

99. Olayinka AT, Oyemakinde A, Balogun MS, Ajudua A, Nguku P, Aderinola $M$, et al. Seroprevalence of Hepatitis B infection in Nigeria: a national survey. Am J Trop Med Hyg. 2016;95(4):902-7.

100. Oluboyo BO, Ugochukwu VI, Oluboyo AO, Ihim AC, Chukwuma GO, Ogenyi JE, et al. Prevalence of hepatitis $b$ and $c$ viral infections in pregnant women attending antenatal clinic in nnewi, Nigeria. Eur Sci J. 2014:10(3):1857-7431.

101. Omatola CA, Lawal C, Omosayin DO, Okolo MO, Adaji DM, Mofolorunsho CK, et al. Seroprevalence of HBV, HCV, and HIV and associated risk factors among apparently healthy pregnant women in Anyigba, Nigeria. Viral Immunol. 2019;32(4):186-91.
102. Omeje KN, Ibekwe RC, Ojukwu JO, Una AF, Ibe BC. Risk factors for hepatitis B surface antigenaemia among secondary school students in Abakaliki, South Eastern Nigeria. Niger J Paediatr. 2017;44(1):14.

103. Onwuakor CE, Eze VC, Nwankwo IU, Iwu JO. Sero-prevalence of Hepatitis B Surface Antigen ( $\mathrm{HBsAg}$ ) amongst pregnant women attending antenatal clinic at the Federal Medical Centre Umuahia, Abia State, Nigeria. Am J Public Health Res. 2014;2(6):255-9.

104. Onwuiri FC, Ndako JA, Onwuliri EA. Prevalence of hepatitis B virus (HBV) and hepatitis $\mathrm{C}$ virus (HCV) and their effects on serum albumin and liver aminotransferases in pregnant women in Jos. Virol Res Rev. 2017:1(2):1-4.

105. Osho PO, Osho ES, Oluwole MT, Fasipe OJ, Koledoye VO, Oni Ol, et al. Seroprevalence rates and awareness of hepatitis $B$ and $C$ viral infections among pregnant antenatal women attending the state specialist hospital Akure, Ondo State, Nigeria. Med J DY Patil Vidyapeeth. 2019;12(5):426

106. Oyinloye SO, Bukbuk DN, Sanda FA. Surveillance of Hepatitis B Biomarkers in Borno State, Nigeria. J Adv Med. 2018. https://doi.org/10.9734/ JAMMR/2018/v28i1030033.

107. Rabiu AB, May OC, Bello SA, Ibrahim AF, Musa A, Bello A, et al. Serosurveillance and risk factors of Hepatitis $B$ virus among pregnant women in Sokoto, North-Western Nigeria. Int STD Res Rev. 2018;7:1-9.

108. Sadoh AE, Sadoh WE, Iduoriyekemwen NJ. HIV co-infection with hepatitis $B$ and $C$ viruses among Nigerian children in an antiretroviral treatment programme. S Afr J Child Health. 2011;5(1):7-10.

109. Sadoh AE, Ofili A. Hepatitis B infection among Nigerian children admitted to a children's emergency room. Afr Health Sci. 2014;14(2):377-83.

110. Davidson UN, Chidiebele NI, Josephine El, Olakunle OE, Nnaemeka IA, Chijioke EJ, et al. The prevalence liver function and immunologic status of children with HIV and Hepatitis B virus coinfection in Enugu, Nigeria. Afr J Infect Dis. 2016:10(2):61-8.

111. Yakubu A, Sahabi DM, Umar AA, Saidu Y, Magaji UF. Prevalence of HBsAg among prospective blood donors and pregnant women in Kebbi State, Nigeria. Niger J Basic Appl Sci. 2016;24(1):57-63.

\section{Publisher's Note}

Springer Nature remains neutral with regard to jurisdictional claims in published maps and institutional affiliations.
Ready to submit your research? Choose BMC and benefit from:

- fast, convenient online submission

- thorough peer review by experienced researchers in your field

- rapid publication on acceptance

- support for research data, including large and complex data types

- gold Open Access which fosters wider collaboration and increased citations

- maximum visibility for your research: over $100 \mathrm{M}$ website views per year

At BMC, research is always in progress.

Learn more biomedcentral.com/submissions 